\title{
'WE KNOW WHAT TO SAY, WE KNOW WHAT TO WRITE, BUT WE DON'T KNOW HOW': THE CHALLENGES OF BECOMING ACADEMICALLY LITERATE IN A NEW LINGUISTIC AND SOCIO-CULTURAL SPACE
}

\section{Emmanuel Sibomana}

University of Rwanda

Email: esibomana1@gmail.com

\section{ABSTRACT}

Historically, some languages and discourses which were initially localised subsequently became regionally or even globally dominant. Currently, English is the dominant global language in all domains, including the academic. Thus academics and scholars from non-English backgrounds are at a disadvantage: they have to adhere to academic literacy conventions in a language in which they may not be completely proficient. This article discusses findings from a study of challenges experienced by a group of postgraduate students from Rwanda whose main languages are Kinyarwanda and French, but whose studies and research at a South African university were in English. Data were collected through questionnaires administered to 21 students and through interviews with four of these students and with three lecturers/research supervisors. Assignment tasks and lecturers' feedback on assignments and research work were also analysed. The findings suggest that, besides the challenges of studying and researching through the medium of English, these students' previous academic 'ways with words' differ from those expected by their lecturers and research supervisors. This article offers a critical discussion of these differences and

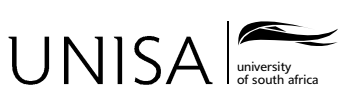

Education as Change

Volume 20 | Number 2 | 2016 | pp. 123-144

www.educationaschange.co.za

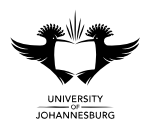

DOI: http://dx.doi.org/10.17159/1947-9417/2016/747 Print ISSN 1682-3206 | Online 1947-9417

(C) 2016 The Author(s) 
of the strategies adopted by students to master 'the right English' to cross academic borders. It raises questions about academic borders and academics as border guards.

Keywords: International students; Non Native English Speakers (NNES); academic discourse; medium of instruction; postgraduate studies; research; second/additional language; foreign language; interim literacies; academic border crossing; academic border guards

\section{INTRODUCTION}

The internationalisation of their postgraduate programmes is a well established item on the agendas of many universities that promote themselves as welcoming international postgraduate students (Cadman 2000; Storch \& Tapper 2009). Abasi and Graves (2008) define international students as students who come from different parts of the world to study in countries other than their own. Many of these students may find the new academic contexts different from their previous ones in terms of academic requirements (Erlenawati 2005; Wu, Garza \& Gazman 2015). In addition, international postgraduate students may be faced with the challenge of studying in a language (of that institution) that they have only previously encountered as a school subject and not as a medium of instruction. This situation may be a source of challenges for these students because the ability to use the medium of instruction competently and confidently is central to academic success (Burke \& Wyatt-Smith 1996; Deem \& Brehony 2000; Coleman 2004; Evans \& Green 2007; Abasi \& Graves 2008; Harrington \& Roche 2014) and difficulties in using it contribute to problems experienced by students in completing their studies (Deem \& Brehony 2000). This is because language mediates communication and, therefore, serves as a 'link between the learner and the teacher' (Rollnick 2000, 95). This article reports and discusses findings of a study which investigated challenges faced by a group of Rwandan postgraduate students, whose main languages were Kinyarwanda and French, but who were studying and researching in English in the School of Education at a South African university.

\section{LITERATURE REVIEW}

Globally, English is the leading language in academic settings (Bhatt 2001; Harrington \& Roche 2014) and in almost all spheres of life (Bhatt 2001; Altbach 2004), functioning as a global academic lingua franca (Canagarajah 2002; Seidlhofer 2005; Lillis 2008; Lillis \& Curry 2010) mainly due to its powerful position in the global economic, media, academic and entertainment spheres (Coleman 2004). As various scholars (for example Altbach 2007; Mauranen, Hynninen, \& Ranta 2010 and Crystal 2012) point out, English has become a global language for science, 
scholarship, and instruction as never before. In short, 'any literate educated person is in a very real sense deprived if he (sic) does not know English' (Phillipson 1997, 5, citing Burchfield 1985). As a result, scholars from around the world are under considerable pressure to write and publish in English (Lillis \& Curry 2010).

However, studying and publishing in English does not come easily to NNES and scholars for whom English is a second/additional or foreign language (Lillis \& Curry 2010). In addition to mastering informal communicative English, these students and scholars have to master academic English as a matter of urgency in order to understand their disciplines and to be successful learners (Hyland \& Hamp-Lyons 2002). In fact, the ability to use academic discourse is a sine qua non for achieving academic success and for demonstrating that achievement (Papashane \& Hlalele 2014). Unfortunately, in addition to being disadvantaged by their limited knowledge of informal, communicative or 'everyday' English (Paxton 2007), many postgraduate students who enrol for tertiary education at English medium universities lack fluency and accuracy in academic English both because English is still a second/additional or foreign language for many of them (Cummins 1996; Cadman 2000; Cheng 2013; Harrington \& Roche 2014) and because they were not initiated into academic literacy in English in their previous studies. In her discussion of language use in the science classroom, Rollnick (2000) points out that Non Native English Speakers (NNES) are doubly challenged: they need to learn both 'everyday' and academic English. This is because, as argued by a number of language education scholars (such as Rollnick 2000; Boughey 2000; Gee 2004; Thesen \& van Pletzen2006; Paxton 2007; McKenna 2010; Paxton \& Frith 2013), academic discourse is a particular variety of English, not like the variety students (even English first language speakers) commonly use. Indeed, some students who have a good command of everyday English, which Gee (2004) terms a vernacular variety, have been found to struggle with academic discourses (Boughey 2000) because this variety is not associated with the complex and technical ways of thinking, which are needed for successful learning (Gee 2004). Thus, all students (including Native Speakers of English - NES) need to acquire academic language (Paxton \& Frith 2013).

However, while Bourdieu, Passeron and de Saint Martin $(1994,8)$ argue that academic language is 'no one's mother tongue, not even that of children of the cultivated class', Gee (2004) suggests that children from middle class homes have an advantage which less privileged children do not have. They get a head start at home before they go to school and continue to receive support outside of school regarding the acquisition of academic language varieties because 'they can tie the words and structures of those languages to experiences which they have had' (Gee 2004, 3). According to Cheng (2013), the complex acquisition of these types of language poses additional challenges for students from the working class, such as the Rwandan students ${ }^{1}$ who participated in the study on which this article

1 While there is no clear distinction between social classes in Rwanda, the social background of 
reports. Such remarks as the above suggest that children from middle and upper classes are more privileged by higher education academic practices. The situation becomes worse for the students from lower socioeconomic classes who, at the same time, are NNES. With specific reference to NNES studying through the medium of English, Rollnick states, it is unreasonable to expect them to learn a new and difficult subject through the medium of a second language because it gives them a double task: mastering both science content and language or becoming 'initiated into two social practices at once' (Rollnick 2000, 100). Cummins (1996) suggests that a task in which a first language student succeeds with little contextual support is likely to be more challenging for a second language student. Findings of Evans and Green's (2007) study of Hong Kong's tertiary students' difficulties with English for Academic Purposes (EAP) suggest that the students experienced greater difficulty with language. This finding suggests that even when the students understand content and are academically literate in another language, their intellectual abilities might be misinterpreted and/or misrepresented due to language difficulties. In fact, students need to have enough proficiency in the language of learning and teaching in order 'to show their understanding of, or be able to negotiate with/argue over content' (Turner 2004, 104).

Given the predominance in academic culture of conventions from the centre (the western world) and of English as a language of global scholarship, graduate students and scholars from the periphery, ${ }^{2}$ are seriously disadvantaged. As Canagarajah (2002) notes, these students and scholars are usually speakers of English as a second/additional or foreign language who are not always familiar with academic writing conventions of the centre and whose own conventions of knowledge making, production and dissemination are not recognised. According to Kutz, Groden and Zamel $(1993,78)$, failure to express their ideas in the academic language conventions of the 'Centre' results in them being 'seen as not having any ideas, as being incapable of doing academic work'. Therefore, 'the relay'(language) rather than 'the relayed'(content) (Bernstein 2000) is used as a benchmark to judge these scholars' and students' academic works which is likely to result in their knowledge and meanings being marginalised (Thesen \& van Pletzen 2006). In fact, as Canagarajah (2002) indicates, academic writing plays a central role in the process of legitimising (and de-legitimising) knowledge.

NNES students' language-related challenges are likely to be greater if the students have to use a language of instruction that they have encountered only as a school subject in their previous studies (Burke \& Wyatt-Smith 1996), as was the case for most of the students who participated in the study discussed in this article.

the Rwandan students who participated in the study corresponds to what is usually known as a working class.

2 The term periphery, according to Canagarajah (2002), refers to communities colonised by European intervention or, in other words, the countries of the political South. 
In this case, the students will find it difficult to play the four roles of a reader as suggested by Freebody and Luke (1990). These roles are (i) code breaker, or being able to decode the text, (ii) text participant or being able to interact with the text and re-write its meaning, (iii) text user or being able to decide what one wants to use the text for and (iv) text analyst, which entails the ability to understand the ideologies of the writer as put in the text and how these ideologies attempt to position the reader. According to Freebody and Luke (1990), the fourth role is related to critical thinking, the development of which is one of the prime aims of education. These scholars argue that readers need to be able to play all four roles in order to comprehend a text. This is especially required at the postgraduate level where, according to Akindele (2008), students are expected to evaluate arguments and evidence and draw reasonable conclusions.

In order to address language-related challenges, NNES are likely to adopt various strategies, with some of the most common being the use of bilingual dictionaries (Peters \& Fernandez 2013), increased interactions with native and other proficient speakers of English (Myles \& Cheng 2003), and cooperative and peer learning (Cummins 1996; Leki 2006). Other strategies include recording lessons and listening to the recording later at home (Burke \& Wyatt-Smith 1996), reading English disciplinary texts, cognitively storing information in previous languages of education, translating the concepts from English to these languages (Ferenz 2005), having their assignments edited by more knowledgeable colleagues and writing in their first languages first, and then translating their assignments into English with the help of people who know English better (Uzuner 2008). The (in)effectiveness of these strategies is discussed in the findings sections.

The universities that enrol these students also need to provide them with support because, as argued by Uzuner (2008), they have the potential to make unique contributions to the knowledge base of core disciplinary communities. Some forms of university and lecturer support include familiarising students with institutional literacy and academic practices through bridging courses (Jones, Turner \& Street 1999; Evans \& Green 2007), establishing sound relationships between students and lecturers (Cummins 1996; Leki 2006), orientation programmes (Cadman 2000; Abasi \& Graves 2008), pedagogic support in the form of extra classroom sessions and extra time for assignments and examinations (Benesch 2001). Interestingly, some university systems and lecturers work as academic border guards ${ }^{3}$ rather than as facilitators of a smooth transition between 'old' and 'new' discourses and environments, notably by labelling NNES as 'the other' (Haugh 2008) or 'at risk students' and considering and/or treating them as a 'burden' or a threat to teaching

3 I used the term academic border guards to refer to mechanisms and/or people which/who make sure that people whose academic abilities are in doubt do not get into the university system. They (academic border guards) are concerned about the standards of the university being lowered if anyone is taken in; thus they take various selective measures to protect academic borders. 
and learning outcomes (Harrington \& Roche 2014). Such treatment complicates further the students' task of adapting to the new academic environment.

\section{METHODOLOGY}

The research discussed in this paper is based on a case study (Gilham 2000; Hancock \& Algozzine 2006) of challenges experienced by 22 Rwandan French-speaking postgraduate students (three honours, 13 masters and six PhDs) who were studying in the School of Education at a South African university. Of these 22 students, ten were university lecturers and/or researchers in Rwanda while 12 held positions in the Ministry of Education. Data were collected by administering questionnaires to 21 students (the researcher was the other student in this group) and by conducting interviews with four of them and with three lecturers/research supervisors. 19 of the questionnaires were completed and returned. Artefacts such as assignment tasks and lecturers' feedback on assignments and research work were also analysed in relation to what students had claimed about aspects of their academic literacy practices when filling in questionnaires and answering interview questions.

A grounded theory approach, defined as a qualitative research approach that uses a systematic set of procedures to develop an inductively derived grounded theory about a phenomenon (Strauss \& Corbin 1997; 1998), was used to analyse data. The theory involved 'open coding' to identify provisional concepts and 'axial coding' to seek connections between the categories identified. A Likert Scale (McMillan \& Schumacher 2006) was also used to analyse participants' responses to two questions in order to understand their perceptions of the level of difficulty they experienced with regards to academic literacy. For ethical purposes, pseudonyms (Isabel, Moses, Frank and John) are used in discussing the interviews.

\section{FINDINGS}

This section reports on the findings of the study with a focus on three aspects. These are (i) the nature of the challenges faced by the students, (ii) the strategies which these students used to address these challenges and (iii) the support offered by the university to these students in their struggle to reach their academic goals.

\section{THE CHALLENGES FACED BY THE STUDENTS}

The students who participated in this study had limited knowledge of English: they were all taught English as a subject at various stages of their education mainly by inexperienced teachers, without adequate teaching/learning aids and in conditions that did not foster optimal motivation (Gardner 1985) for, and investment (Norton 2000) in, studying this language. For example, Moses indicated that he had not 
found any reason to study English because he was proficient in French while Isabel indicated that the English she had been taught at high school was substandard. In addition to studying English in less than ideal circumstances, only one respondent reported having used it in his work. ${ }^{4}$ Moreover, with the exception of three students who specialised in English in their bachelor's and master's degree studies, others had not had access to academic English.

It should be noted that there were mismatched expectations between the university lecturers and most of the students who took part in this study. Being aware of their limited knowledge of English, the students had expected the university to provide them with language support before they began studying degree courses or working on their research projects. However, the university assumed that the students enrolled with an awareness that they were at an English medium university and therefore that they were ready to study in English.

\section{THE CHALLENGES OF USING ENGLISH IN SPOKEN AND WRITTEN ACADEMIC DISCOURSES}

Generally, the respondents indicated that studying and researching in English was a source of difficulties. Indeed, the majority of respondents (thirteen) indicated that using everyday English (let alone academic English) was a challenge for them; they were frustrated by their failure to express themselves as they wished. One $\mathrm{PhD}$ student, Isabel, expressed her feelings as follows:

We know what to say, we know what to write, but we don't know how. I wonder how I will present my research proposal if I manage to write it up! When I speak, I am not self-confident in front of the academic community since I wonder whether my English is at the level of academics. Sometimes, this prevents me from expressing myself fluently.

It then follows that studying and researching in English was even more challenging and, according to all four respondents who were interviewed, an obstacle to academic progress and performance. Moses said:

If I were doing my research in a language which I understand better I would have gone much further. But now I spend most of my time checking the meanings of words in dictionaries, their spelling, their pronunciation...

Frank believed that his level of academic performance would be higher if he were using a language that he could understand better. John said that if he were using French, he would not need 'to turn his head twice' to understand recommended readings. He pointed out that he had to grapple with English before understanding the content. John's remarks echo Rollnick's (2000) claim that NNES have to struggle

4 Being a university lecturer in the English Department, this respondent had used English in tutoring/lecturing. 
with language first before accessing the content. Thus, they have to 'fight two enemies' (Brock-Utne 2000): the language and the subject content.

With reference to their struggle to understand content in English and make themselves understood, the respondents' perceptions contradict much of what has been written about the 'skills' which NNES find easier or more difficult to acquire. In fact, the respondents considered writing and reading easier than listening and speaking in contrast to findings from numerous studies (e.g. Harrington \& Roche 2014) which indicate that students in settings where English is used as a lingua franca regularly identify academic reading and writing to be of particular concern as these 'skills' are difficult to acquire and develop successfully for a range of reasons. For instance, writing is multidimensional (Storch 2009) and the written language is usually considered more challenging because it uses lower frequency vocabulary and is not supported by the context, gestures and intonation, all of which 'make conversational language easier to understand' (Cummins 1996, 80). However, while suggesting that reading and writing were easier than listening and speaking, the Rwandan students did acknowledge that they experienced difficulties with the former because of their previously limited exposure to reading and writing in English. For instance, one respondent acknowledged that he had not read an English text of more than three pages before coming to the South African university, while three said that they experienced writing in English for the first time when they came to this university.

The most common explanation given by the respondents for listening and speaking being more difficult was that while the respondents had written and read texts in English (though to a limited extent) they had not had opportunities to speak and/or to listen to spoken English. One of them indicated that his stay in South Africa was his first opportunity to speak English and that, therefore, people should not expect much from him in this regard. Now that the students had to interact with more proficient speakers of English who, according to Isabel, 'speak very fast swallowing some words', speaking and listening became a great challenge. Thus, these students' perceptions need to be linked to the students' educational background to be understood fully. For instance, Moses indicated that the grammar he had studied at high school enabled him to write better than he speaks. This may imply that his writing abilities are better than his listening and speaking abilities, which does not necessarily mean that his writing is generally good.

Indeed, looking at the respondents' writing (on the questionnaire) closely, it appears that some of them still had problems in writing good (everyday) English. For example, the following are one respondent's reasons why she thought that studying at the University of the Witwatersrand would improve her English proficiency. While these responses can be understood, neither is written in Standard English:

That help to use some of my english already I know and to acquire other new knowledge. 
When asked to give her view about the English support training offered to the Rwandan students by the university she wrote:

That helps me to improve my english language, but the methodology which they used, it was not better for the beginners.

These examples suggest that these students did not understand the kind of writing requirements that were awaiting them at the new university, which points to the aforementioned mismatched expectations.

The respondents were asked to indicate the extent to which specific aspects of academic writing were easy/difficult for them and their answers are summarised in Table ${ }^{5}$ below:

Table 1: Rating of aspects of academic writing according to level of difficulty

\begin{tabular}{|l|l|l|l|l|l|l|}
\hline Item & $\begin{array}{l}\text { Very } \\
\text { easy }\end{array}$ & Easy & Neutral & Difficult & $\begin{array}{l}\text { Very } \\
\text { difficult }\end{array}$ & Total \\
\hline Writing introductions & 0 & $\mathbf{9}$ & $\mathbf{4}$ & 3 & 1 & 17 \\
\hline Referring to sources & 1 & $\mathbf{1 4}$ & $\mathbf{0}$ & 1 & 1 & 17 \\
\hline Revising written work & 0 & $\mathbf{8}$ & $\mathbf{5}$ & 3 & 0 & 16 \\
\hline Writing references/bibliography & 2 & $\mathbf{1 0}$ & $\mathbf{3}$ & 0 & 1 & 16 \\
\hline Writing conclusions & 0 & $\mathbf{1 0}$ & $\mathbf{3}$ & 4 & 0 & 17 \\
\hline Writing 'body sections' & 0 & $\mathbf{8}$ & $\mathbf{6}$ & 3 & 0 & 17 \\
\hline Summarising/paraphrasing & 0 & 3 & 7 & 6 & 1 & 17 \\
\hline Planning written assignments & 0 & 5 & 7 & 5 & 0 & 17 \\
\hline $\begin{array}{l}\text { Expressing ideas clearly/ } \\
\text { logically }\end{array}$ & 0 & 4 & 7 & 5 & 1 & 17 \\
\hline Synthesising information & 0 & 5 & 6 & 6 & 0 & 17 \\
\hline Writing coherent paragraphs & 0 & 7 & 4 & 3 & 1 & 15 \\
\hline $\begin{array}{l}\text { Proofreading written } \\
\text { assignments }\end{array}$ & 0 & 5 & 7 & 3 & 1 & 16 \\
\hline Linking sentences smoothly & 0 & 4 & 5 & 7 & 1 & 17 \\
\hline $\begin{array}{l}\text { Expressing ideas in correct } \\
\text { English }\end{array}$ & 0 & 2 & 5 & 5 & 4 & 16 \\
\hline $\begin{array}{l}\text { Using appropriate academic } \\
\text { style }\end{array}$ & 0 & 0 & 5 & 9 & 3 & 17 \\
\hline
\end{tabular}

5 The two tables used in this article were adapted from one developed by Evans and Green (2007). 
The responses presented in Table 1 indicate that writing introductions, referring to sources, revising written work, writing references/bibliographies, writing conclusions and writing 'body sections' are considered to be easier than the remaining aspects. This may be because this set of knowledge and skills applies to all languages (to varying degrees) and respondents had written 'academic texts' before (BA/BSc and/or masters dissertations) mainly in French. By contrast, the remaining sets of knowledge and skills (except planning written assignments) necessarily require knowledge of English for academic purposes, which many of them did not have. However, the respondents' written texts reveal difficulties even with those aspects that they claimed were easy or about which they were neutral. For instance, a paragraph from an essay written by Frank, who pointed out that 'expressing ideas clearly' is easy for him, reads as follows:

Flinders and Thornton (2004) refer to Goodlad's critic of national curriculum reform in his book; School curriculum in the United States where he is questioning about how curriculum content is determined and the way it should be teaching. Draws on Dewey (1938) views he argues that curriculum content should be designed according to children-centered and society-oriented.

The main idea in the above paragraph which, apparently, is what Goodlad is criticising is not specified and his argument is not presented. So, the point which is made in the paragraph is not clear. The lecturer's comment about the paragraph was a question asking what the student meant. Again, while this student indicated that writing introductions was easy for him, the first paragraph of the same essay continued for so long that it became half of the text with no clear indication of where the introduction ended. Moreover, while the student claimed that 'referring to sources' was easy, references were missing for some arguments in his first and second essays as shown by the lecturer's comment/question 'according to...?', which is found in two of this student's three assignments.

To turn from Frank to John, when completing the questionnaire, this informant pointed out that 'referring to sources' was easy for him. However, an examination of one of his essays reveals the opposite. Three times in in-text citations, he wrote almost the entire reference of an article as follows: Mkandawire T: Thinking about developmental states in Africa. Cambridge journal of Economics, 2001, p. 289. He also mentioned the following reference within the text: Edigheji $O$ (2005): A democratic State in Africa? www.aps.org.za. Furthermore, this essay has neither a conclusion nor a reference list (bibliography) in spite of the use of several scholarly works, yet the student claimed that writing a reference list/bibliography and 'writing conclusions' was easy for him. Given that effective writing is part of the academic message (Turner 2004) and an integral part of every student's academic life (Jones, Turner \& Street 1999), there is little doubt that these students' inability to produce academic writing of the quality expected by the university would have negatively affected their academic progress and performance. 
The respondents were also asked to rate aspects of academic reading according to levels of difficulty. The question was answered by 17 participants; another four pointed out that this question was not applicable to them since they did not experience any difficulty with regard to academic reading. The views of the 17 respondents are presented in Table 2 below:

Table 2: Rating of aspects of academic reading according to level of difficulty

\begin{tabular}{|l|l|l|l|l|l|l|}
\hline Item & $\begin{array}{l}\text { Very } \\
\text { easy }\end{array}$ & Easy & Neutral & Difficult & $\begin{array}{l}\text { Very } \\
\text { difficult }\end{array}$ & Total \\
\hline $\begin{array}{l}\text { Identifying supporting ideas/ } \\
\text { examples }\end{array}$ & $\mathbf{1}$ & $\mathbf{9}$ & $\mathbf{4}$ & 3 & 0 & 17 \\
\hline $\begin{array}{l}\text { Reading carefully to } \\
\text { understand a text }\end{array}$ & $\mathbf{2}$ & $\mathbf{1 0}$ & $\mathbf{2}$ & 3 & 0 & 17 \\
\hline Identifying key ideas & $\mathbf{0}$ & $\mathbf{7}$ & $\mathbf{6}$ & 4 & 0 & 17 \\
\hline $\begin{array}{l}\text { Understanding organisation of } \\
\text { a text }\end{array}$ & $\mathbf{1}$ & $\mathbf{8}$ & $\mathbf{5}$ & 2 & 0 & 16 \\
\hline Taking brief, relevant notes & $\mathbf{2}$ & $\mathbf{6}$ & $\mathbf{6}$ & 3 & 0 & 17 \\
\hline $\begin{array}{l}\text { Using own words in note } \\
\text { taking }\end{array}$ & 0 & 4 & 3 & $\mathbf{8}$ & $\mathbf{2}$ & 17 \\
\hline $\begin{array}{l}\text { Reading quickly to get overall } \\
\text { meaning }\end{array}$ & 0 & 6 & 3 & $\mathbf{5}$ & $\mathbf{3}$ & 17 \\
\hline $\begin{array}{l}\text { Reading quickly to find } \\
\text { information }\end{array}$ & 0 & 5 & 4 & $\mathbf{6}$ & $\mathbf{2}$ & 17 \\
\hline $\begin{array}{l}\text { Working out meaning of } \\
\text { difficult words }\end{array}$ & 0 & 5 & 5 & $\mathbf{5}$ & $\mathbf{2}$ & 17 \\
\hline $\begin{array}{l}\text { Understanding specialist } \\
\text { vocabulary }\end{array}$ & 0 & 3 & 4 & $\mathbf{7}$ & $\mathbf{2}$ & 16 \\
\hline
\end{tabular}

The data presented in Table 2 indicate that the students considered the first five aspects to be easier than the rest. This is probably because these skills can be transferred from one language to another (from French to English in this case). For example, as Cummins $(2005,4)$ argues, 'various aspects of a bilingual's proficiency in L1 and L2 are seen as common or interdependent across languages'. It is possible that the students used the knowledge and literacy practices acquired in French as resources to deal with texts in English. The last five aspects largely depend on the students' knowledge of the language being used and these students have a limited vocabulary in English. Therefore, using their own words when taking notes from texts, reading quickly and understanding the meaning of difficult words and specialist vocabulary would pose considerable challenges. 
The essays written by some of these students reveal that they are still struggling with the 'easier' aspects of reading and writing. In one essay John identified key arguments made by different authors in one article. This essay received the following comments from the lecturer: (i) not a key argument of Dale himself, (ii) not a key point and (iii) good, but you started with the unimportant points and finished with the key points of Dale's article. Even though this student pointed out that 'identifying key ideas' is in the neutral category for him, the above comments suggest that he still had difficulties with it. This contradiction between the students' responses and their actual writing suggests that they did not understand the academic literacy requirements of the new space, which implies that these students' previous academic institutions' 'ways with words' (Heath 1983) are different from those at the South African university. Failure to recognise these differences may have been the main reason for the tensions between some of these students and some of their lecturers over the marks awarded for their assignments. The students believed they deserved higher marks than the lecturers had awarded them.

\section{STRATEGIES USED BY THE STUDENTS TO ADDRESS THE CHALLENGES}

With reference to reading, the most salient of these students' strategies was consulting English-French dictionaries and using machine translation to translate the recommended readings into French for better understanding. In addition to a possibility of distorting the original message, relying on bilingual dictionaries and on machine translation is likely to keep the students at Freebody and Luke's (1990) level of code breaker while their studies and research work require them to work as text analysts. Thus, not being able to adopt all four roles of a leader is likely to have negative consequences for students because, as Papashane and Hlalele (2014) argue, literacy is not just about reading a text for information, but being able to put it to some kind of use.

It should be noted that resorting to French was a strategy common to most of the students and the influence of this language was evident in some of their written work as explained by Jennifer, a lecturer/supervisor who also happened to be proficient in French:

I kept on saying [to the students]: 'how would you research that and it is purely a description that is not going anywhere'... Research is asking a question; the question was either (sic) too broad and I think that is an influence from French because the French are very broad in their understanding of any problem in their writing about everything...You have to read pages and pages then you ask a question what are you trying to say? And the student is actually lost at identifying what is being said because they talk about, you know, the background, introduction...but the basic foundation that is needed to get to a particular point and the argument is lost. I think the ability to build an argument in an academic discourse is 
something that the French speaking Africans that I have come across...is not very strongly enhanced by their previous academic systems.

Given that French is the language that introduced the students to the academic world and it is mainly through this language that they had acquired knowledge in their disciplinary field, the French influence seems inevitable. In fact, as argued by Eley and Jennings (2005), the language in which knowledge was acquired and mentally stored is important in the process of writing. In a similar vein, Gee (2012) notes that students use the discourses at their disposal (those in French in this case) in writing and traces of these are evident in the texts that they produce. The students' drawing on their primary language(s) and previous discourses contributes to what Paxton terms 'interim literacies'. She suggests that students 'make meaning by reworking past discourses, appropriating and adapting new discourses to make them their own' $(2007,45)$. Jones, Turner and Street (1999) suggest that students draw on new discourses with varying degrees of success and, according to Paxton (2007), these degrees depend on the degree of similarity between the old and new types of practices, among other factors. Thus, one way of helping students would be to help them to use their 'old discourses' in acquiring the new ones. However, such help can only be offered when lecturers are familiar (at least to some extent) with the students' old discourses. As a starting point, for instance, Jennifer, who understands how the students' discourses in French affect the acquisition of the new ones could assist these students and help other lecturers/research supervisors to do the same.

Concerning writing, the key strategy used by these students was to write in 'their limited English' and then give their work to more knowledgeable colleagues for revision and/or editing. Though some mentioned the existence of a free service at the university's Writing Centre for consultation about draft work, only three of the 21 respondents reported making use of it, with others preferring to consult with colleagues judged more proficient in academic English, usually from Rwanda. Even in peer learning groups they preferred to work together as Rwandans. One reason for this, according to some of the students, was that South African students looked down on them because they were not proficient in English. This situation and its effects, as discussed more extensively by Hunma and Sibomana (2013), may result from the fear of exposing their (the students') weaknesses in the contact zone (Hunma \& Sibomana 2013). As pointed out by Cooper (2013), the contact zone is a site of risk and the students appeared not to be ready to take it. Such fear may have limited their opportunities to adapt and integrate academically and socially. In addition, consulting with other Rwandans was not entirely effective, because these were also in the process of adapting to the university's 'new ways' and, therefore, might not be able to provide appropriate support. 


\section{INSTITUTIONAL SUPPORT OFFERED TO THE STUDENTS}

With reference to institutional support, Angélil-Carter (1998) argues that universities have the responsibility to provide NNES with additional opportunities to absorb and produce the language and the meaning of the discipline. The language support provided by the university for these students was reactive rather than proactive: due to the aforementioned mismatched expectations, the university did not expect the students to need support and when it was realised that some support was needed it was provided in the form of a university-funded course designed to assist students with oral and written English. Those who participated in the course pointed out that it was generally not effective; for some it was too short, for others the methodology was not suited to beginners and others considered the level of the course too low or 'irrelevant' to postgraduate students. The latter group pointed out that they were taught rules for writing such as avoiding long sentences, using linking words between paragraphs, etc., which, according to them, are relatively common in many languages used in higher education (including French). They said that, instead, they expected a course which introduced them to the English academic discourses of their respective areas of specialisation. These varied responses to the course are indicative of the varied needs of the students in this group.

Another important element of support for these students was lecturers and/or research supervisors' responses to their work. These were extremely varied: some lecturers would listen to the students' problems and advise and help in finding solutions whenever possible, encourage and appreciate their efforts, extend deadlines for the submission of assignments, respond positively to students' weaknesses and take care of each and every student individually, notably by allowing them to rewrite their assignment if their mark was less than $60 \%$. Additional tutorials were also offered to the students by some lecturers to provide them with opportunities for more detailed discussion of course content and to ask questions about the issues they found difficult to understand in bigger classes.

On the other hand, some lecturers publicly ridiculed the Rwandan students, indicating that they did not deserve to be studying at postgraduate levels. For example, one interviewee indicated that one lecturer repeatedly made the following remark in class: 'I don't understand why this university accepted the students from Rwanda. How do you admit people who were trained in a system which trained them to reproduce what they read into a system where they have to use critical thinking?'. Such remarks raised the students' affective filter (Krashen 1982) and discouraged them from voicing their ideas in English with only three of the 21 students indicating that they contributed extensively to classroom discussion, 11claiming to contribute to a limited extent while three never asked a question in class. However, even when the students were courageous and determined enough to move forward, some lecturers/ 
research supervisors' comments were discouraging. For instance, after writing his MEd research proposal, one student sought permission from his supervisor to submit it for examination. With reluctance, she signed, but made the following comments:

I have always told you that you are not able to carry out a MEd research, but you decided to push for it. I am signing for you but I don't think this proposal will pass.

This kind of attitude and response from lecturers and/or research supervisors may have both pedagogic and linguistic implications because it is likely to discourage students from playing an active role in, and contributing to, the learning process in ways which are important for effective learning (Vygotsky 1978; Bernstein 2000), especially at the postgraduate level where students' own construction of knowledge is frequently demanded (Hussain 2012). Pedagogically, these responses may work as academic border guards and/or cause the students to feel that they are too weak to complete successfully a border crossing and to graduate. For instance, even though the abovementioned student's proposal was accepted by the examiners, the student decided to use it in order to be awarded a Postgraduate Diploma of Education ${ }^{6}$ rather than developing it, and collecting and analysing data in order to produce a MEd research report. When I asked him why he made this decision he said, 'I don't think I can do masters research under the supervision of that lecturer and succeed'. This student is not the only one who could not cross the border. Seven of the 22 students who participated in this study were awarded PGDEs instead of MEds. For all of these, diplomas were not their first choice: they were imposed on them by the circumstances. Linguistically, the responses may have limited the opportunities for the students to improve their language proficiency in English through making use of the little English they already knew.

In addition, these responses that portray the students as inadequate may also have had negative effects on these students' previous identities as successful professionals and academics and on their successful assumption of the new identity as struggling students. This kind of 'identity crisis' can be inferred from the following remarks by one student explaining why he withdrew from the English support course: 'those who taught us considered us as children who are learning to speak a language'. This statement suggests that this student felt that his identity as an adult and educated person was not respected. This situation seems normal because, as Wenger (1998) argues, new environments constitute unfamiliar territories where old identities are challenged and where they are confronted with the unfamiliar.While Gee (1996) argues that these conflicts between identities are normal to each of us, the level of success with which we navigate through them differ as was the case for the students who participated in this research.

6 A passed proposal at this university's School of Education is considered as a passed module. 


\section{DISCUSSION AND CONCLUSION}

It appears that the challenges faced by the students who were involved in this study were enormous and the effectiveness of the strategies which were used to address them was limited. In fact, seven of the students, all of whom worked in the Ministry of Education, could not complete their MEd research projects and, de facto, their MEd studies. It is likely that one factor contributing to their lack of success in the academy was their failure to acquire and/or adapt to the new discourses successfully or, at least, that they were positioned as unable to do so. It should be noted that for such an acquisition/adaptation to be possible, students need to be enculturated (apprenticed) into social practices through scaffolded and supported interaction with people who have already mastered the discourse (Gee 2012) rather than through explicit teaching. In other words, the students needed to interact sufficiently with more academically and communicatively proficient students (and lecturers) in order to acquire successfully the new discourse, which, according to Deem and Brehony (2000), enhances students' identities as researchers and as members of their academic community. However, the students did not want to move out of their comfort zone because they did not want other members of this new community to see their 'nakedness' and judge them. Some of them also argued that aspects of the university environment, including the negative comments of lecturers/research supervisors previously mentioned, discouraged them from doing so.

As a lecturer and research supervisor, Maria pointed out that social isolation was a serious challenge to the students' development not only linguistically but in the whole of their academic and social life. In fact, literacy, an important aspect of academic success, is bound up with our identity and our practices (Pahl \& Rowsell 2005) and we 'multiply' our identities by extending our social and academic network. The more we extend our social and academic networks, the more we multiply discourses and enrich our literacy practices and 'social positions' (Sheridan, Street $\&$ Bloome 2000) from which to engage in various literacy events and further enrich our repertoire of literacy practices. Referring to social opportunities, Gee (2012) notes that lack of access to a range of social identities may lead to social isolation. For Swales (1990), individuals may belong to several discourse communities and individuals will vary in the number of discourse communities they belong to and hence in the number of genres they command. The perceived lack of opportunities for the Rwandan students who participated in this research to participate in social activities with local students may have impacted negatively on their literacy practices and academic success. In addition, it appears that institutional support for these students was almost non-existent. As has been pointed out, the support which was provided by the university for the students in this study was reactive, improvised and largely ineffective. Indeed, most of those who took part in the language support course could not undertake masters research and write research reports. In addition, instead of working as facilitators of learning, some lecturers worked as academic 
border guards, considering these students as threats to the university's face (Hunma \& Sibomana 2013) and, therefore, preventing them from being members of the university community, because they were from an academic tradition which was not recognised by the university. This approach contradicts a guiding principle of inclusive education which states that whoever comes to our learning institutions are the right people (Morgan \& Houghton 2011). This principle implies that what makes a difference is how the institutions respond to the students' needs.

In fact, the students' previous academic 'ways with words' (Heath 1983), one of the resources that could have been used to foster an improved understanding of 'the new' academic language (Lee 2005; Paxton 2007; Nambiar, Ibrahim \& Meerah 2012) and to adapt to new discourse communities (Gee 2012), were either ignored or sometimes 'fought' against by the lecturers. The practice of imposing university/ ies' own academic discourses and ignoring those of postgraduate students/scholars from the periphery is exercised by the 'centre' universities and by many academic journals (Lillis \& Curry 2010). However, given the variation of academic discourses across the regions (Lillis \& Curry 2010) some universities in the periphery are closer to the 'centre' than others and act/behave as such, with the South African university at which the Rwandan students were located arguably being such a university. In view of the findings of this study, a number of questions arise: to what extent should international students be expected to conform to the academic literacy and research practices of the host institution? Can mismatched expectations be avoided? If so, how? What could lead to the construction of more confident student identities? While I do not have definite answers to these questions, I suggest that, instead of expecting the students to use the 'new language' as if by magic, universities should help these students to transition progressively from the 'old' to the 'new' language. One way to achieve this is to identify, value and build on what these students and scholars have 'brought along' (Hunma \& Sibomana 2013), which could boost their self-confidence. Whatever the answers may be, failure to adapt to the new academic environment and discourses by international NNES students results in great wastage for both the students and the institutions that they join and this is a situation that will continue for some time as the numbers of these students keep increasing (Storch \& Tapper 2009; Harrington \& Roche 2014). Thus, the institutions that enrol international students need to put in place effective support structures for these students to remedy this situation.

Moreover, given that tensions between promoting the reproduction of dominant discourses while encouraging students to preserve their own voices and helping them to succeed in their target discourse communities may be irresolvable (Tardy 2006), students and lecturers should, at least, be aware of these tensions and try to negotiate 'spaces' for responding to them. Thus, improved communication between applicants for postgraduate studies and lecturers within particular academic disciplines, in relation to English for Academic Purposes (EAP) and to research traditions, may 
promote selection for success and effective assistance such as the provision of sustained discipline-focused academic literacy support (Leki 2006). Given that the dominance of English as a global academic language is likely to continue (Canagarajah 2002; Lillis \& Curry 2010) and students who apply for postgraduate studies are expected to be conversant with academic literacies in English which, according to Paxton and Frith (2013), play a key role in learning and concept development, perhaps the time has come for all institutions of higher learning globally to equip their students at undergraduate level with academic literacy in English.

\section{ACKNOWLEDGEMENT}

I would like to acknowledge the contribution of Professor Yvonne Reed to this article. In addition to helping me present the conference paper which this article originates from, she commented on the draft of the article at different stages, which contributed to making the article what it is now.

\section{REFERENCES}

Abasi, A.R. and B. Graves. 2008. Academic literacy and plagiarism: Conversations with international graduate students and disciplinary professors. Journal of English for Academic Purpose 7(4): 221-233.

Akindele, O. 2008. A critical analysis of the literature review section of graduate dissertations at the University of Botswana. ESP 7(20): 1-20.

Altbach, P.G. 2004. Globalization and the university: Myths and realities in an unequal world. Tertiary Education and Management 10(1): 3-25.

Altbach, P.G. 2007. The imperial tongue: English as the dominating academic language. Economic and Political Weekly 42(36): 3608-3611.

Angélil-Carter, S., ed. 1998. Access to success: Literacy in academic contexts. Cape Town: University of Cape Town Press.

Benesch, S. 2001. Critical English for academic purposes. Mahwah, NJ: Lawrence Erlbaum Associates.

Bernstein, B. 2000. Pedagogy, symbolic control and identity: Theory, research, critique. Revised edition. Oxford: Rowman \& Littlefield Publishers.

Bhatt, R.M. 2001. World Englishes. Annual Review of Anthropology 30: 527-550.

Boughey, C. 2000. Multiple metaphors in an understanding of academic literacy. Teachers and Teaching: Theory and Practice 6(3): 279-290.

Bourdieu, P., J.C. Passeron and M. de Saint Martin. 1994. Academic discourse. Cambridge: Polity Press.

Brock-Utne, B. 2000. Language of instruction in Tanzania and Namibia. Whose education for all? The recolonization of the African mind. New York and London: Falmer Press.

Burke, E. and C. Wyatt-Smith. 1996. Academic and non-academic difficulties: Perceptions of graduate non-English speaking background students. Teaching English as a Second or 
Foreign Language 2(1). Retrieved from: http://www.tesl-ej.org/wordpress/issues/volume2/ ej05/ej05a1/ (accessed 17 November 2014).

Cadman, K. 2000. Voices in the air: Evaluations of the learning experiences of international postgraduates and their supervisors. Teaching in Higher Education 5(4): 475-491.

Canagarajah, S. 2002. A geopolitics of academic writing. Pittsburgh: University of Pittsburgh Press.

Cheng, R. 2013. A non-native student's experience on collaborating with native peers in academic literacy development: A socio-political perspective. Journal of English for Academic Purposes 12(1): 12-22.

Coleman, J.A. 2004. English-medium teaching in European higher education. Language Teaching 39(1): 1-14.

Cooper, B. 2013. Both dead and alive: Schrodinger's cat in the contact zone. In Risk in academic writing: Postgraduate students, their teachers and the making of knowledge. Edited by L. Thesen and L. Cooper, 245-251. Ontario: Multilingual Matters.

Crystal, D. 2012. English as a global language. New York: Cambridge University Press.

Cummins, J. 1996. Negotiating identities: Education for empowerment in a diverse society. Ontario, CA: CABE.

Cummins, J. 2005. Teaching for cross-language transfer in dual language education: Possibilities and pitfalls. Paper presented at the TESOL Symposium on Dual Language Education:Teaching and Learning Two Languages in the EFL Setting, September 23, Bogazici University, Istanbul, Turkey.

Deem, R. and K.J. Brehony. 2000. Doctoral students' access to research cultures-Are some more unequal than others? Studies in Higher Education 25(2): 149-165.

Eley, A.R. and R. Jennings. 2005. Effective postgraduate supervision: Improving the student supervisor relationship. Berkshire: Open University Press.

Erlenawati, S. 2005. Language difficulties of international students in Australia: The effects of prior learning experience. International Education Journal 6(5): 567-580.

Evans, S. and C. Green. 2007. Why EAP is necessary: A survey of Hong Kong tertiary students. Journal of English for Academic Purposes 6(1): 3-17.

Ferenz, O. 2005. EFL writers' social networks: Impact on advanced academic literacy development. Journal of English for Academic Purposes 4(4): 339-351.

Freebody, P. and A. Luke. 1990. Literacies programs: Debates and demands in cultural context. Australian Journal of TESOL 5(3): 7-16.

Gardner, R.C. 1985. Social psychology and second language learning: The role of attitudes and motivation. London: Edward Arnold.

Gee, J.P. 1996. Social linguistics and literacies: Ideology in discourse. New York: Falmer Press.

Gee, J.P. 2004. Situated language and learning: A critique of traditional schooling. New York and London: Routledge.

Gee, J.P. 2012. Social linguistics and literacies: Ideology in discourse. $4^{\text {th }}$ edition. New York: Routledge.

Gillham, B. 2000. Case study research methods. London: Continuum. 
Hancock, D.R. and B. Algozzine. 2006. Doing case study research: A practical guide for beginning researchers. New York: Teacher College Press.

Harrington, M. and T. Roche. 2014. Identifying academically at-risk students in an English-as-alingua-franca university setting. Journal of English for Academic Purposes 15: 37-47.

Haugh, M. 2008. The discursive negotiation of international student identities. Discourse: Studies in the Cultural Politics of Education 29(2): 207-222.

Heath, S.B. 1983. Ways with words: Language, life and work in communities and classrooms. Cambridge: Cambridge University Press.

Hunma, A. and E. Sibomana. 2013. Academic writing and research at an Afropolitan university: An international student perspective. In Risk in academic writing: Postgraduate students, their teachers and the making ofknowledge. Edited by T. Lucia and L. Cooper, 100-128. Ontario: Multilingual Matters.

Hussain, I. 2012. Use of constructivist approach in higher education: An instructors' observation. Creative Education 3(2): 179-184.

Hyland, K. and L. Hamp-Lyons. 2002. EAP: Issues and directions. The Journal of English for Academic Purposes 1(1): 1-12.

Jones, C., J. Turner and B. Street, eds. 1999. Students writing in the university: Cultural and epistemological issues. Amsterdam, Philadelphia: John Benjamins.

Kutz, E., S.Q. Groden and V. Zamel. 1993. The discovery of competence: Teaching and learning with diverse student writers. Portsmouth: Boynton/Cook Heinemann.

Lee, O. 2005. Science education with English language learners: Synthesis and research agenda. Review of Educational Research 75(4): 491-530.

Leki, I. 2006. Negotiating socio academic relations: English learners' reception by and reaction to college faculty. The Journal of English for Academic Purposes 5(2): 136-152.

Lillis, T. 2008. Trajectories of knowledge production: English medium academic writing for national, transnational and international journals: Full Research Report, ESRC End of Award Report, RES-000-22 - 2234. Swindon: ESRC.

Lillis, T.M. and M.J. Curry. 2010. Academic writing in a global context: The politics and practices of publishing in English. New York: Routledge.

Mauranen, A., N. Hynninen and E. Ranta. 2010. English as an academic lingua franca: The ELFA project. English for Specific Purposes 29(3): 183-190.

McKenna, S. 2010. Cracking the code of academic literacy: An ideological task. In Beyond the university gates: Provision of extended curriculum programmes in South Africa. Edited by C. Hutchings and J. Garraway, 8-15. Grahamstown: Rhodes University.

McMillan, J.H. and S. Schumacher. 2006. Research in education: Evidence-based inquiry. New York: Pearson Education.

Morgan, H. and A.M. Houghton. 2011. Inclusive curriculum design in higher education: Considerations for effective practice across and within subject areas. The Higher Education Academy. Retrieved from: https:/www.heacademy.ac.uk/sites/default/files/resources/ Introduction\%20and\%20ov erview.pdf (accessed 10 December 2014).

Myles, J. and L. Cheng. 2003. The social and cultural life of non-native English speaking international graduate students at a Canadian university. Journal of English for Academic Purposes2(3): 247-263. 
Nambiar, R.M.K., N. Ibrahim and T.S.M Meerah. 2012. Literacy encounters in a nonanglophone context: Korean study abroad students in a Malaysian classroom. Asian Social Science 8(7): $110-118$.

Norton, B. 2000. Identity and language learning: Gender, ethnicity and educational change. Harlow, England: Longman/Pearson Education.

Pahl, K. and J. Rowsell. 2005. Literacy and education: Understanding the new literacy studies in the classroom. London: Paul Chapman.

Papashane, M. and D. Hlalele. 2014. Academic literacy: A critical cognitive catalyst towards the creation of sustainable learning ecologies in higher education. Mediterranean Journal of Social Sciences 5(10): 661-671.

Paxton, M. 2007. Students' interim literacies as a dynamic resource for teaching and transformation. South African Linguistic and Applied Language Studies 25(1): 45-55.

Paxton, M. and V. Frith. 2013. Positioning academic literacies at the core of curriculum design. Paper presented at the HELTASA Conference, 26-29 November, UNISA, Pretoria.

Peters, P. and T. Fernandez. 2013. The lexical needs of ESP students in a professional field. English for Specific Purposes 32(4): 236-247.

Phillipson, R. 1997. Linguistic imperialism. Oxford: Oxford University Press.

Rollnick, M. 2000. Current issues and perspectives on second language learning of science. Studies in Science Education 35: 93-122.

Seidlhofer, B. 2005. English as a lingua franca. ELT Journal 59(4): 339-341.

Sheridan, D., B.V. Street and D. Bloome. 2000. Writing ourselves: Mass observation and literacy practices. Cresskill: Hampton Press.

Storch, N. 2009. The impact of studying in a second language (L2) medium university on the development of L2 writing. Journal of Second Language Writing 18(2): 103-118.

Storch, N. and J. Tapper. 2009. The impact of an EAP course on postgraduate writing. Journal of English for Academic Purposes 8(3): 207-223.

Strauss, A.L. and J.M. Corbin, eds. 1997. Grounded theory in practice. New Delhi: SAGE.

Strauss, A.L. and J.M. Corbin. 1998. Basics of qualitative research: Techniques and procedures for developing grounded theory. New Delhi: SAGE.

Swales, J.M. 1990. Genre analysis: English in academic and research settings. Cambridge: Cambridge University Press.

Tardy, C. 2006. Appropriation, ownership, and agency: Negotiating teacher feedback in academic settings. In Feedback in second language writing: Contexts and issues. Edited by K. Hyland and F. Hyland, 61-72.New York: Cambridge University Press.

Thesen, L. and E. van Pletzen. 2006. Introduction: The politics of place in academic literacy work. In Academic literacy and the languages of change. Edited by L. Thesen and E. van Pletzen, 1-29. London: Continuum.

Turner, J. 2004. Language as academic purpose. Journal of English for Academic Purpose 3(2): 95-109.

Uzuner, S. 2008. Multilingual scholars' participation in core/global academic communities: A literature review. Journal of English for Academic Purposes 7(4): 250-263.

Vygotsky, L.S. 1978. Mind in society. Cambridge, MA: MIT Press. 
Wenger, E. 1998. Communities of practice: Learning, meaning, and identity. Cambridge: Cambridge University Press.

Wu, H., E. Garza and N. Gazman. 2015. International students' challenges and adjustment to college. Article ID 202753, 9 pages. Education Research International. Retrieved from: http://www.hindawi.com/journals/edri/2015/202753/ (accessed 24 June 2015). 